\title{
Amplification of glutathione-mediated oxidative stress by catalase in an aqueous solution at hyperthermal temperatures
}

\author{
Megumi Ueno, ${ }^{\dagger}$ Emiko Sekine-Suzuki, ${ }^{\dagger}$ Minako Nyui, Ikuo Nakanishi and Ken-ichiro Matsumoto* \\ Quantitative RedOx Sensing Team, Department of Basic Medical Sciences for Radiation Damages, National Institute of Radiological Sciences, \\ National Institutes for Quantum and Radiological Science and Technology, 4-9-1 Anagawa, Inage-ku, Chiba-shi, Chiba 263-8555, Japan
}

(Received 7 March, 2016; Accepted 18 July, 2016; Published online 24 February, 2017)

\begin{abstract}
The glutathione (GSH)-mediated superoxide $\left(\mathrm{O}_{2}{ }^{--}\right)$generation in an aqueous solution and relation of hydrogen peroxide $\left(\mathrm{H}_{2} \mathrm{O}_{2}\right)$ and effect of catalase were investigated. $\mathrm{GSH}$-induced $\mathrm{O}_{2}{ }^{--}$generation in hyperthermal temperatures was measured by the nitroblue tetrazolium (NBT) mehod. Heating an aqueous solution containing GSH caused superoxide from dissolved $\mathrm{O}_{2} \cdot \mathrm{H}_{2} \mathrm{O}_{2}$ was generated simultaneously in this reaction mixture probably from the hydroperoxy radical $\left(\mathrm{HO}_{2}{ }^{\circ}\right)$, which is equilibrated with $\mathrm{O}_{2}{ }^{--}$in an aqueous condition, and then $\mathrm{H}_{2} \mathrm{O}_{2}$ consumed $\mathrm{O}_{2}{ }^{\circ-}$. Coexisting catalase in the reaction mixture, as a result, could increase $\mathrm{O}_{2}{ }^{--}$generation. The catalase-exaggerated extracellular $\mathrm{O}_{2}{ }^{--}$generation could give a harmful effect to living cells. This GSH-induced oxidative stress can be a part of mechanisms of hyperthermia therapy.
\end{abstract}

Key Words: $\quad$ superoxide, hydroperoxy radical, hydrogen peroxide, hyperthermia, redox

$\mathrm{R}$ educed form glutathione (GSH) has been recognized as a major endogenous antioxidant in living cells. GSH is a tripeptide, consisted of glutamic acid, cystein, and glycine. GSH has a thiol on the cysteine moiety and can work as a hydrogen donor, i.e., a direct reductant. Another important biological antioxidative role of GSH is as a coenzyme of glutathione peroxidases (GSH-Px), which catalyzes decomposition of hydrogen peroxide $\left(\mathrm{H}_{2} \mathrm{O}_{2}\right)$ to harmless water $\left(\mathrm{H}_{2} \mathrm{O}\right)$ using $\mathrm{GSH}$, forming oxidized glutathione (GSSG). The reaction catalyzed by glutathione reductase recovers GSH from GSSG using nicotinamide adenine dinucleotide phosphate (NADPH) as a coenzyme. Therefore, it can be stated generally that the GSH protects living cells from oxidative injury directly and/or indirectly.

On the other hand, there are several reports about oxidative action of glutathione and other thiol compounds. In late 1950s, formation of $\mathrm{H}_{2} \mathrm{O}_{2}$ in solution of glutathione with oxygen was reported. ${ }^{(1)}$ Lehninger and Schneider ${ }^{(2)}$ reported that GSH and cysteine cause mitochondrial swelling and that redox state between cytochrome $c$ and oxygen is as a determinant. The participation of thiol groups in the oxidative destruction of hemoglobin was examined and be concern. ${ }^{(3)}$ Hoffsten et al. ${ }^{(4)}$ reported that the GSH-induced mitochondrial swelling is closely associated with lipid peroxidation. The glutathione induced mitochondrial swelling and lipid peroxidation model has been further studied over subsequent several years. ${ }^{(5,6)}$ In addition, it was reported that the autoxidation of GSH and/or other thiols yields superoxide. ${ }^{(7)}$ Oxidative actions of GSH and other thiols has been reported not so much but occasionally and continuously. ${ }^{(8-12)}$

Recently, temperature dependent generation of superoxide $\left(\mathrm{O}_{2}{ }^{--}\right)$ in an aqueous solution containing GSH was reported. ${ }^{(13,14)}$ Incubating a reaction mixture containing 4-hydroxyl-2,2,6,6- tetramethylpiperidine- $N$-oxyl (TEMPOL) and GSH at $44^{\circ} \mathrm{C}$, the TEMPOL shows a steep reduction following a short time delay. This characteristic TEMPOL reduction was halted by adding superoxide dismutase (SOD) to the reaction mixture or bubbling $\mathrm{N}_{2}$ gas through the reaction mixture. This result suggests that generation of $\mathrm{O}_{2}{ }^{--}$from dissolved oxygen is related to the observed TEMPOL reduction. Importantly, the temperature dependent reaction of GSH suggests variable behavior of GSH depending on the experimental conditions.

A number of researchers may have experiences that the GSH added as an antioxidant sometimes shows unanticipated paradoxical actions in their test tubes, whether they have reported or ostracized their unexpected results in their experiments. The temperature dependent oxidative actions of GSH through $\mathrm{O}_{2}{ }^{-}$ formation may be one reason of the paradoxical biochemical behaviors of GSH. The $\mathrm{O}_{2}{ }^{--}$formation can inevitably generate $\mathrm{H}_{2} \mathrm{O}_{2}$. However, a clear chemical model mechanism of aggressive oxidative action of GSH has not been proposed.

In this paper, $\mathrm{GSH}$-induced $\mathrm{O}_{2}^{\cdot-}$ generation in hyperthermal temperatures was again confirmed by the nitroblue tetrazolium (NBT) mehod. The NBT method is a conventional assay for determining $\mathrm{O}_{2}{ }^{--}$, which can reduce NBT to make a blue formazan having absorption at $560 \mathrm{~nm}$. A relation of $\mathrm{H}_{2} \mathrm{O}_{2}$ simultaneously generated in the reaction mixture and effect of catalase was also investigated. Chemical mechanisms and possible harmful effect of the GSH-induced oxidative effect were described.

\section{Methods}

Chemicals. GSH, NBT, and catalase from bovine liver (CAT) were purchased from Wako Chemical (Tokyo, Japan). TEMPOL and SOD from human erythrocytes were purchased from SigmaAldrich (St. Louis, MO). Other chemicals used in this study were of analytical grade. As the basic solvent of reaction mixtures, $100 \mathrm{mM}$ phosphate buffer (PB) $(\mathrm{pH} \mathrm{7.0)}$ containing $0.05 \mathrm{mM}$ diethylenetriaminepentaacetic acid (DTPA) (100 mM PB) was prepared and used for all experiments. Deionized water (Milli-Q system, Merck Millipore, Billerica, MA) was used for preparing $100 \mathrm{mM}$ PB.

Preparation of reaction mixture and measurement of absorbance. Reaction mixtures containing NBT, GSH, TEMPOL SOD, CAT, and/or $\mathrm{H}_{2} \mathrm{O}_{2}$ were prepared with $100 \mathrm{mM}$ $\mathrm{PB}$ to make the final concentrations of contents shown in Table 1. The reaction mixture was kept in a quartz cuvette $(1 \mathrm{~cm})$, and

${ }^{\dagger}$ Equally contributed to this work.

*To whom correspondence should be addressed.

E-mail: matsumoto.kenichiro@qst.go.jp 
Table 1. Composition of reaction mixtures tested

\begin{tabular}{|c|c|c|c|c|c|}
\hline No. & NBT (mM) & TEMPOL (mM) & GSH (mM) & Other conditions & Result \\
\hline 1 & - & 0.1 & 1.0 & - & Fig. $1 \mathrm{~A}$ \\
\hline 2 & 1.0 & 0.1 & 1.0 & - & Fig. 1A \\
\hline 3 & 1.0 & 0.1 & - & - & Fig. 1B \\
\hline 4 & 1.0 & 0.1 & 1.0 & - & Fig. 1B \\
\hline 5 & 1.0 & 0.1 & 1.0 & $1.6 \mathrm{U} / \mathrm{ml} \mathrm{SOD}$ & Fig. $1 \mathrm{C}$ \\
\hline 6 & 1.0 & 0.1 & 1.0 & $0.5 \mathrm{~L} / \mathrm{min} \mathrm{N}_{2}$ bubbling & Fig. $1 \mathrm{C}$ \\
\hline 7 & 1.0 & - & - & - & Fig. $2 A$ \\
\hline 8 & 1.0 & - & 1.0 & - & Fig. 2A \\
\hline 9 & 1.0 & - & 1.0 & $1.6 \mathrm{U} / \mathrm{ml} \mathrm{SOD}$ & Fig. 2B \\
\hline 10 & 1.0 & - & 1.0 & $0.5 \mathrm{~L} / \mathrm{min} \mathrm{N}_{2}$ bubbling & Fig. 2B \\
\hline 11 & 1.0 & - & - & $1 \mathrm{mM} \mathrm{GSSG}$ & Fig. 2B \\
\hline 12 & 1.0 & - & 1.0 & at $50^{\circ} \mathrm{C}, 44^{\circ} \mathrm{C}, 37^{\circ} \mathrm{C}$, or RT & Fig. 3 \\
\hline 13 & - & 0.1 & $0.5-8.0$ & at $37^{\circ} \mathrm{C}$ & Fig. 4A \\
\hline 14 & - & 0.1 & $0.5-8.0$ & at $44^{\circ} \mathrm{C}$ & Fig. 4B \\
\hline 15 & 1.0 & - & $0.5-8.0$ & at $37^{\circ} \mathrm{C}$ & Fig. $5 \mathrm{~A}$ \\
\hline 16 & 1.0 & - & $0.5-8.0$ & at $44^{\circ} \mathrm{C}$ & Fig. 5B \\
\hline 17 & 1.0 & - & 1.0 & $250 \mathrm{U} / \mathrm{ml}$ Catalase & Fig. $6 \mathrm{~A}$ \\
\hline 18 & 1.0 & - & 1.0 & $500 \mathrm{U} / \mathrm{ml}$ Catalase & Fig. 6A \\
\hline 19 & 1.0 & - & 1.0 & $1,000 \mathrm{U} / \mathrm{ml}$ Catalase & Fig. 6A \\
\hline 20 & 1.0 & - & 1.0 & $0.1 \mathrm{mM} \mathrm{H}_{2} \mathrm{O}_{2}$ & Fig. 6B \\
\hline 21 & 1.0 & - & 1.0 & $0.5 \mathrm{mM} \mathrm{H}_{2} \mathrm{O}_{2}$ & Fig. 6B \\
\hline 22 & 1.0 & - & 1.0 & $1.0 \mathrm{mM} \mathrm{H}_{2} \mathrm{O}_{2}$ & Fig. 6B \\
\hline
\end{tabular}

$\mathrm{RT}$, room temperature.

was incubated at an arbitrary steady temperature in the spectral photometer (Hitachi, Japan), which was equipped with a water flow temperature control system. Time course of absorbance at $560 \mathrm{~nm}$ of the reaction mixture was measured. The measurement was triplicated for each composition of the reaction mixtures.

$\mathrm{X}$-band electron paramagnetic resonance measurement. The reaction mixture was kept in a vial, and was incubated at $44^{\circ} \mathrm{C}$ in the water bath. An aliquot $(120-130 \mu \mathrm{l})$ of the reaction mixture was sampled in a quartz flat cell. Then, the flat cell containing sample solution was set in a TE-mode cavity using a special cell holder and measured as soon as possible. The sample solution in the flat cell was put back into the vial immediately after measurement. The time course of the electron paramagnetic resonance (EPR) signal height of the TEMPOL signal was plotted. The EPR conditions were as follows: microwave frequency was $9.4 \mathrm{GHz}$, microwave power was $4 \mathrm{~mW}$, center field was $334 \mathrm{mT}$, sweep width was $10 \mathrm{mT}$, sweep speed was $5 \mathrm{mT} / \mathrm{min}$, modulation frequency was $100 \mathrm{kHz}$, modulation amplitude was $0.079 \mathrm{mT}$, and time constant was $0.03 \mathrm{~s}$.

Mouse thymus cell surviving. Effect of GSH-induced $\mathrm{O}_{2}{ }^{--}$ to living cells was tested by a cell survival test of rodent thymus cell. ${ }^{(15)}$ Healthy 7-week-old Female $\mathrm{C} 3 \mathrm{H} / \mathrm{He} / \mathrm{Slc}$ mice were supplied by Japan SLC, Inc. (Shizuoka, Japan). Animals were housed five per cage in climate controlled $\left(23 \pm 1{ }^{\circ} \mathrm{C}\right.$ and $55 \pm 5 \%$ humidity), circadian rhythm-adjusted ( $12 \mathrm{~h}$ light-dark cycle) rooms and were allowed food and water ad libitum until the experiments. The mice were used for experimentation at an age of 21 weeks old $(25.2 \pm 2.0 \mathrm{~g}, n=10)$. The thymus was surgically removed from a mouse. Thymocytes were squeezed out of the thymus with tweezers, put into a phosphate buffered saline (PBS), and passed through mesh to disassemble to the single cell. The cells at a density of $5 \times 10^{5}$ cells/tube were preliminary administrated with a $1.0 \mathrm{mM} \mathrm{GSH}$ and/or $1,000 \mathrm{U} / \mathrm{ml} \mathrm{CAT}$ and incubated at $37^{\circ} \mathrm{C}$ or $44^{\circ} \mathrm{C}$ for $2 \mathrm{~h}$, and then, the cells were spin down at $600 \times g$ for $5 \mathrm{~min}$, re-suspended in PBS alone, and were incubated at $37^{\circ} \mathrm{C}$ for another $2 \mathrm{~h}$. After the incubation, measurement of cell size was performed using a flow cytometry FACSCalibur (Becton, Dickinson and Company, Franklin Lakes, NJ). Experiments were carried out in compliance with and approved by the Animal Use
Committee of the National Institute of Radiological Sciences, Chiba, Japan.

\section{Results and Discussion}

For comparison with the previous paper, ${ }^{(14)}$ which used a basic reaction mixture formula containing $0.1 \mathrm{mM}$ TEMPOL and $1 \mathrm{mM}$ $\mathrm{GSH}$, at first in this paper, the same formula of reaction mixture except containing $1.0 \mathrm{mM}$ NBT was tested. Incubating the reaction mixture containing TEMPOL, GSH, and NBT at $44^{\circ} \mathrm{C}$, the EPR signal of TEMPOL in the reaction mixture was reduced with the characteristic curve shape (Fig. 1A) similar to as shown in the previous paper. ${ }^{(14)}$ Simultaneously, the yellow/orange color of reaction mixture was changed to blue, and absorption at $560 \mathrm{~nm}$ increased, however, no increase of absorbance at $560 \mathrm{~nm}$ was observed without GSH (Fig. 1B). The increasing of the absorbance at $560 \mathrm{~nm}$ was suppressed when the $1.6 \mathrm{U} / \mathrm{ml}$ SOD was added in the reaction mixture or when the reaction mixture was bubbled by $0.5 \mathrm{~L} / \mathrm{min} \mathrm{N}_{2}$ gas (Fig. 1C). Therefore, the GSHdependent increasing absorbance at $560 \mathrm{~nm}$ at $44^{\circ} \mathrm{C}$ in this experiment is suggesting generation of $\mathrm{O}_{2}{ }^{--}$.

The source of $\mathrm{O}_{2}^{--}$must be dissolved molecular oxygen $\left(\mathrm{O}_{2}\right)$, since $\mathrm{N}_{2}$ bubbling in the reaction mixture could suppress the reaction (Fig. $1 \mathrm{C}$ and $2 \mathrm{~B}$ ). The GSH may give a hydrogen radical $\left({ }^{\circ} \mathrm{H}\right)$, and the dissolved $\mathrm{O}_{2}$ could be directly reduced by a ${ }^{\cdot} \mathrm{H}$ as below to give a hydroperoxyl radical $\left(\mathrm{HO}_{2}{ }^{\circ}\right)$ [Eq. 1 and 2]. The $\mathrm{HO}_{2}{ }^{\circ}$ is in equilibrium with the $\mathrm{O}_{2}^{-}$in aqueous solution [Eq. 3]. Intermediating ${ }^{\circ} \mathrm{H}$ and $\mathrm{GS}^{\circ}$ is in progress. The reactions 1,2 and 4 may be one-step reaction. The point is that GSH can reduce $\mathrm{O}_{2}$ temperature dependently.

$$
\begin{aligned}
& \mathrm{GSH} \leftrightarrow{ }^{\cdot} \mathrm{H}+\mathrm{GS}^{\cdot} \\
& { }^{\circ}+\mathrm{O}_{2} \rightarrow \mathrm{HO}_{2} \cdot \\
& \mathrm{HO}_{2} \cdot \leftrightarrow \mathrm{H}^{+}+\mathrm{O}_{2}{ }^{\cdot-}
\end{aligned}
$$

Consequently GSSG can result from a reaction between a pair of GS:

$\mathrm{GS}^{\bullet}+\mathrm{GS}^{\bullet} \rightarrow \mathrm{GSSG}$ 

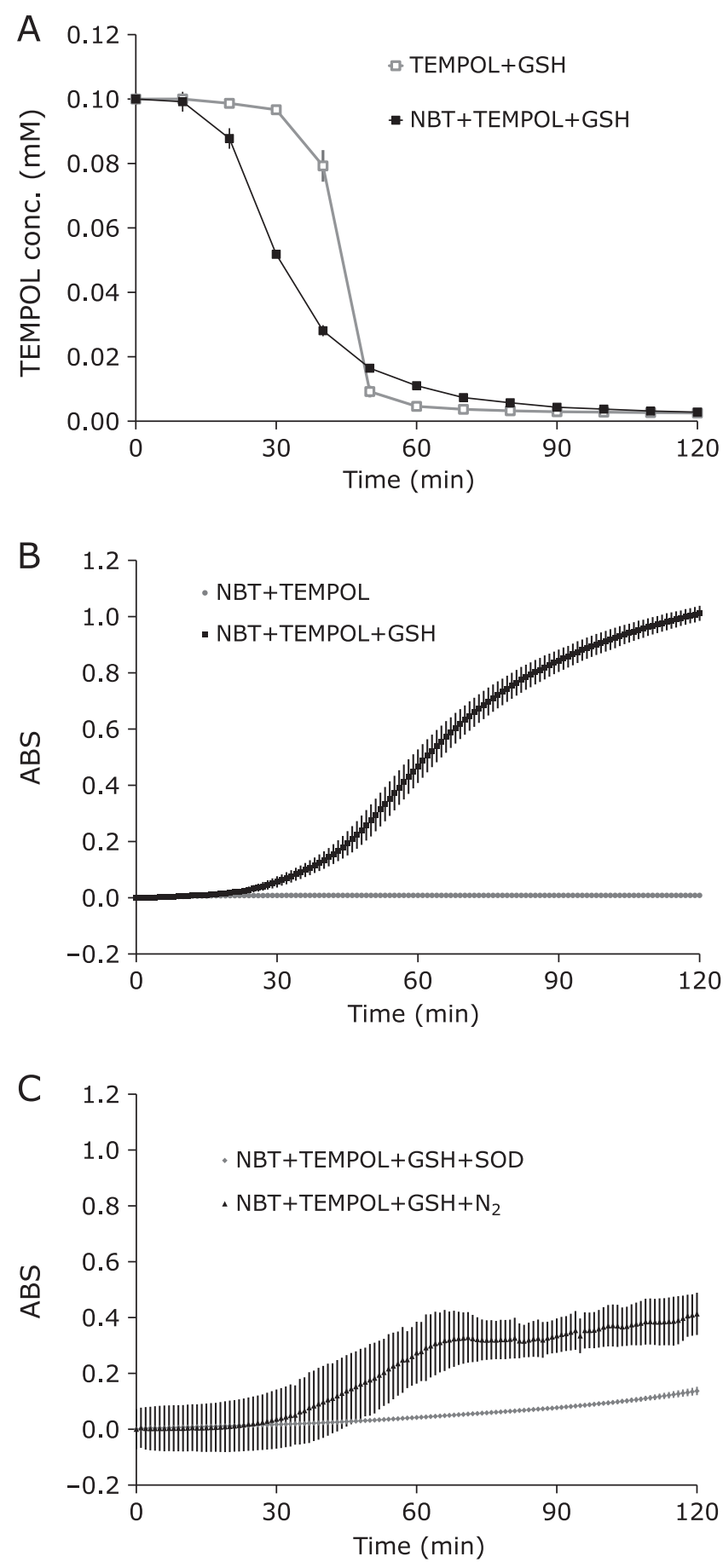

Fig. 1. Comparison of the reaction profiles of GSH-dependent reduction of TEMPOL and the GSH-dependent formation of blue formazan (reduced NBT) at hyperthermal temperatures. (A) Reaction mixture containing $0.1 \mathrm{mM}$ TEMPOL and $1.0 \mathrm{mM} \mathrm{GSH}$ was incubated at $44^{\circ} \mathrm{C}$ for 120 min with (black square) or without (gray square) $1.0 \mathrm{mM} \mathrm{NBT}$. (B) Reaction mixtures containing $1 \mathrm{mM}$ NBT and $0.1 \mathrm{mM}$ TEMPOL were incubated with (black squares) or without $1 \mathrm{mM}$ GSH (gray circles). (C) Reaction mixtures containing $1 \mathrm{mM}$ NBT, 0.1 TEMPOL, and $1 \mathrm{mM} \mathrm{GSH}$ were incubated with $1.6 \mathrm{U} / \mathrm{ml}$ SOD (gray diamonds) or with bubbling $\mathrm{N}_{2}$ gas (black triangles). Values are indicated as averages of triplicated experiments \pm SD.

The active products in this reaction are actually both $\mathrm{HO}_{2}{ }^{\circ}$, which is a relatively strong oxidant, and $\mathrm{O}_{2}{ }^{-}$, which is basically a reductant.
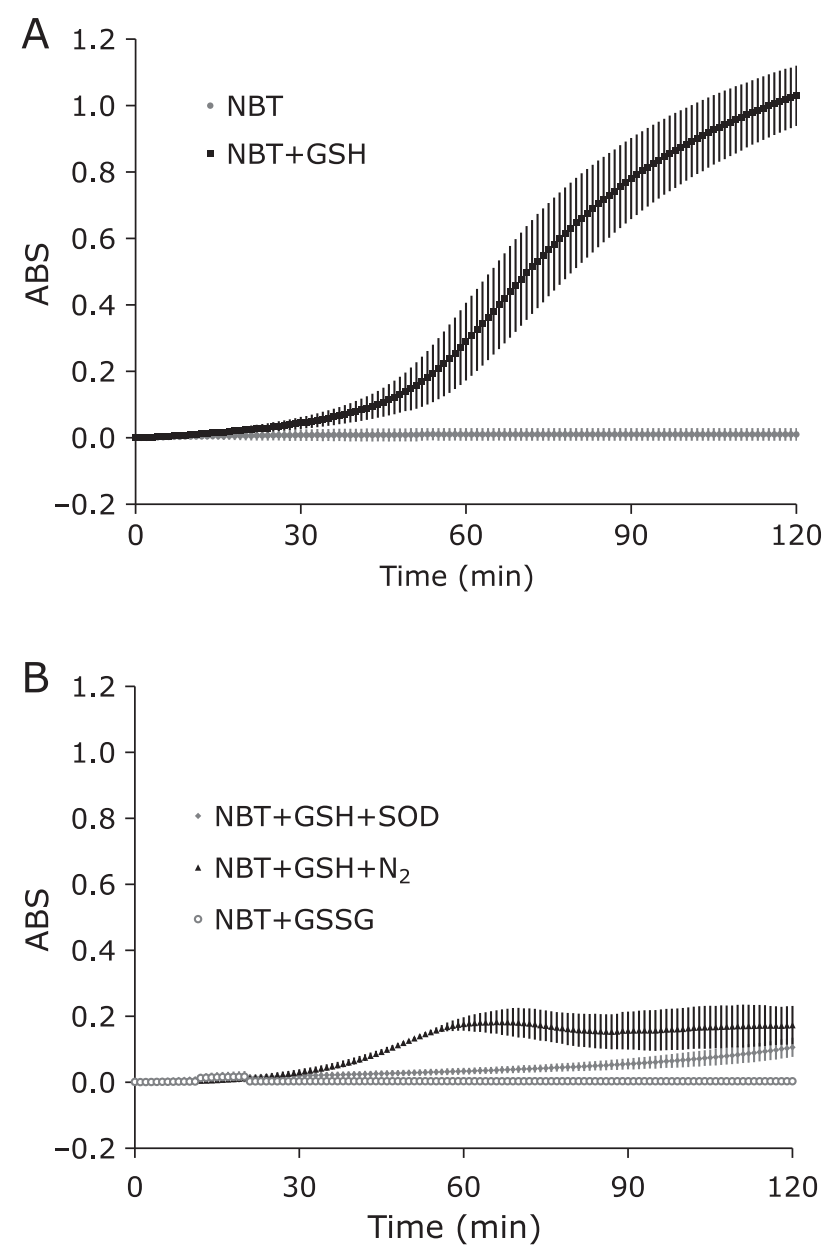

Fig. 2. Evaluation of the effect of TEMPOL on the formation of the blue formazan (reduced NBT). The reaction mixture was incubated at $44^{\circ} \mathrm{C}$ for $120 \mathrm{~min}$. (A) Reaction mixtures containing $1 \mathrm{mM}$ NBT were incubated with (black squares) or without $1 \mathrm{mM}$ GSH (gray circles). (B) Reaction mixtures containing $1 \mathrm{mM} \mathrm{NBT}$ and $1 \mathrm{mM}$ GSH was incubated with $1.6 \mathrm{U} / \mathrm{ml}$ SOD (gray diamonds), with bubbling $\mathrm{N}_{2}$ gas (black triangles), or the case that $1 \mathrm{mM}$ GSSG was added instead of GSH. Values are indicated as averages of triplicated experiments \pm SD.

Halliwell ${ }^{(16)}$ proposed a different reaction mechanism of GSHdependent $\mathrm{O}_{2}{ }^{--}$generation, which is the reduction of $\mathrm{O}_{2}$ by $\mathrm{GSSG}^{{ }^{-}}$. In their reaction, GS ${ }^{*}$ was initially given by a reaction of GSH and other free radical species such as ${ }^{\circ} \mathrm{OH}$, and then $\mathrm{GSSG}^{\cdot-}$ was given by a reaction of GS' and GSH. In our reaction system, however, it is quite unlikely that the other free radicals participate the formation of $\mathrm{GS}^{\cdot}$ and/or ${ }^{\circ} \mathrm{H}$.

The actual trigger of the TEMPOL reduction should be oneelectron-oxidation of TEMPOL by $\mathrm{HO}_{2}{ }^{\cdot}$ to give an oxoamonium cation form of TEMPOL. The oxoamonium cation form of TEMPOL then could react with GS ${ }^{*}$ to make a stable nonparamagnetic complex and as a result TEMPOL was two-electronreduced. ${ }^{(13)}$ On the other hand, NBT can be directly reduced by $\mathrm{O}_{2}{ }^{--}$to give blue formazan dye. Strong reductants, such as ascorbic acid, can also reduce NBT and give the blue formazan (data not shown).

Adding NBT in the reaction mixture made the decaying TEMPOL a little faster and the delay time shorter (Fig. 1A). The nitroxyl radical form of TEMPOL can be one-electron-oxidized by $\mathrm{HO}_{2} \cdot$ to be the oxoamonium cation form. In an opposite way, the oxoamonium cation can be one-electron-reduced by $\mathrm{O}_{2}{ }^{--}$to recover the nitroxyl radical. The reduction of NBT by $\mathrm{O}_{2}{ }^{--}$, which 


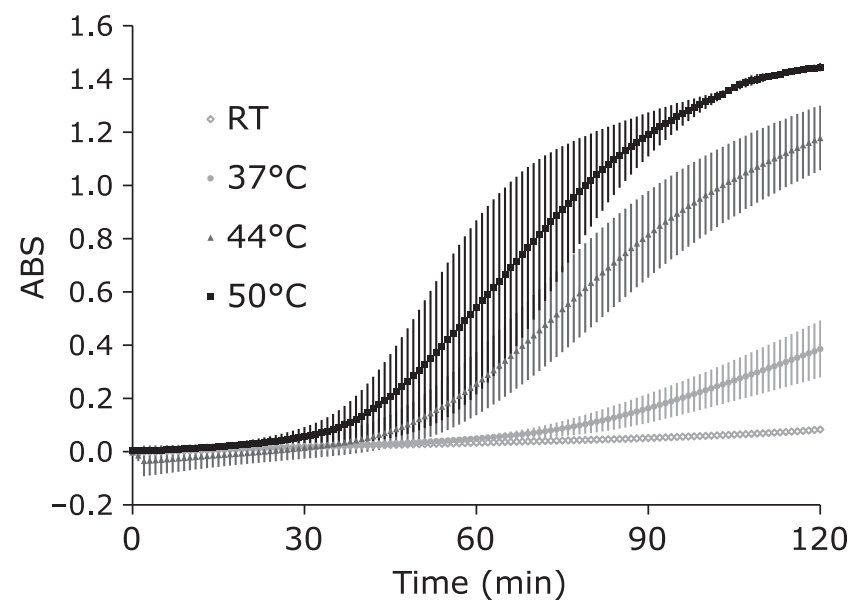

Fig. 3. Temperature dependent formation of the blue formazan (reduced NBT). The reaction mixture containing $1.0 \mathrm{mM}$ NBT and $1.0 \mathrm{mM}$ GSH was incubated at $50^{\circ} \mathrm{C}, 44^{\circ} \mathrm{C}, 37^{\circ} \mathrm{C}$, or room temperature for $120 \mathrm{~min}$. Values are indicated as averages of triplicated experiments \pm SD.
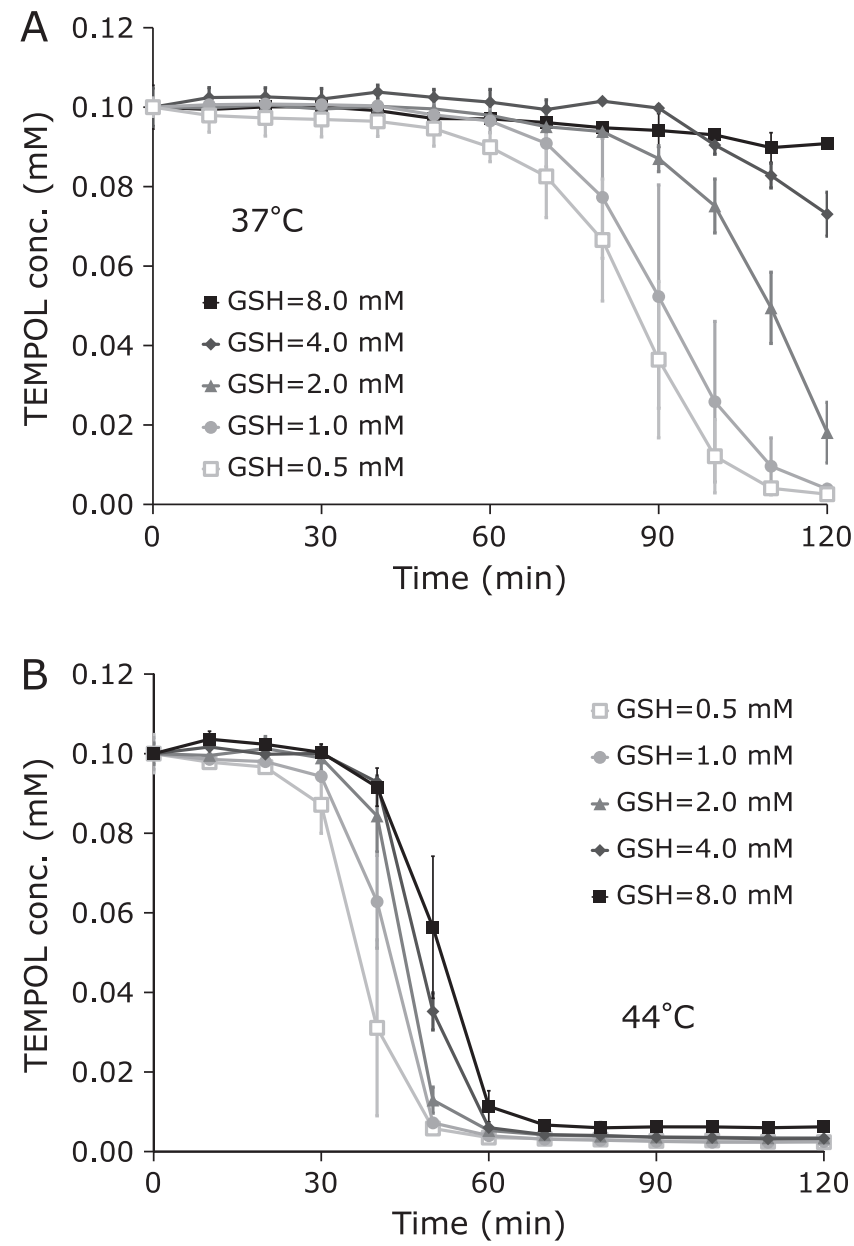

Fig. 4. Effect of GSH concentration on the reduction of TEMPOL. The reaction mixtures containing $0.1 \mathrm{mM}$ TEMPOL and several different GSH concentrations were incubated at (A) $37^{\circ} \mathrm{C}$ or (B) $44^{\circ} \mathrm{C}$ for $120 \mathrm{~min}$ Values are indicated as averages of triplicated experiments \pm SD. can also be recognized as the consumption of $\mathrm{O}_{2}^{--}$by NBT, may suppress reduction of the oxoamonium cation form to a nitroxyl radical form, and apparently accelerate one-electron-oxidation of TEMPOL to the oxoamonium cation form. As a result, quasi-oneelectron-reduction of TEMPOL, i.e., decay of the EPR signal of TEMPOL, could be accelerated. In this case NBT and the oxoamonium cation form of TEMPOL competes each other for $\mathrm{O}_{2}{ }^{--}$. NBT may decrease the population of $\mathrm{O}_{2}{ }^{--}$, but not deplete and allow the presence of $\mathrm{HO}_{2}{ }^{-}$. SOD, however, may deplete $\mathrm{O}_{2}{ }^{-}$, then the equiribrium between $\mathrm{HO}_{2}{ }^{\circ}$ and $\mathrm{O}_{2}{ }^{--}$[Eq. 3] would strongly move to the right. Therefore, SOD does not allow that $\mathrm{HO}_{2}{ }^{\circ}$ could exist. In other words, $\mathrm{HO}_{2}{ }^{-}$rapidly changed to $\mathrm{O}_{2}{ }^{--}$before reacting with other molecules, and then was deleted by SOD.

The next experiment tested whether the TEMPOL had any effect on the generation of $\mathrm{O}_{2}{ }^{--}$. When the reaction mixture containing simply GSH and NBT was incubated at $44^{\circ} \mathrm{C}$, the similar increasing of absorbance at $560 \mathrm{~nm}$ shown in Fig. 1A was observed at almost the same timing (Fig. 2A). However, no increasing absorbance at $560 \mathrm{~nm}$ was observed without GSH (Fig. 2A). The increasing of the absorbance at $560 \mathrm{~nm}$ was suppressed when the $1.6 \mathrm{U} / \mathrm{ml}$ SOD was added in the reaction mixture or when the reaction mixture was bubbled by $0.5 \mathrm{~L} / \mathrm{min}$ $\mathrm{N}_{2}$ gas (Fig. 2B). Since reaction profiles in Fig. 1 and 2 can be evaluated almost similar shapes in considering the variability, the TEMPOL in the reaction mixture has no modification as to the
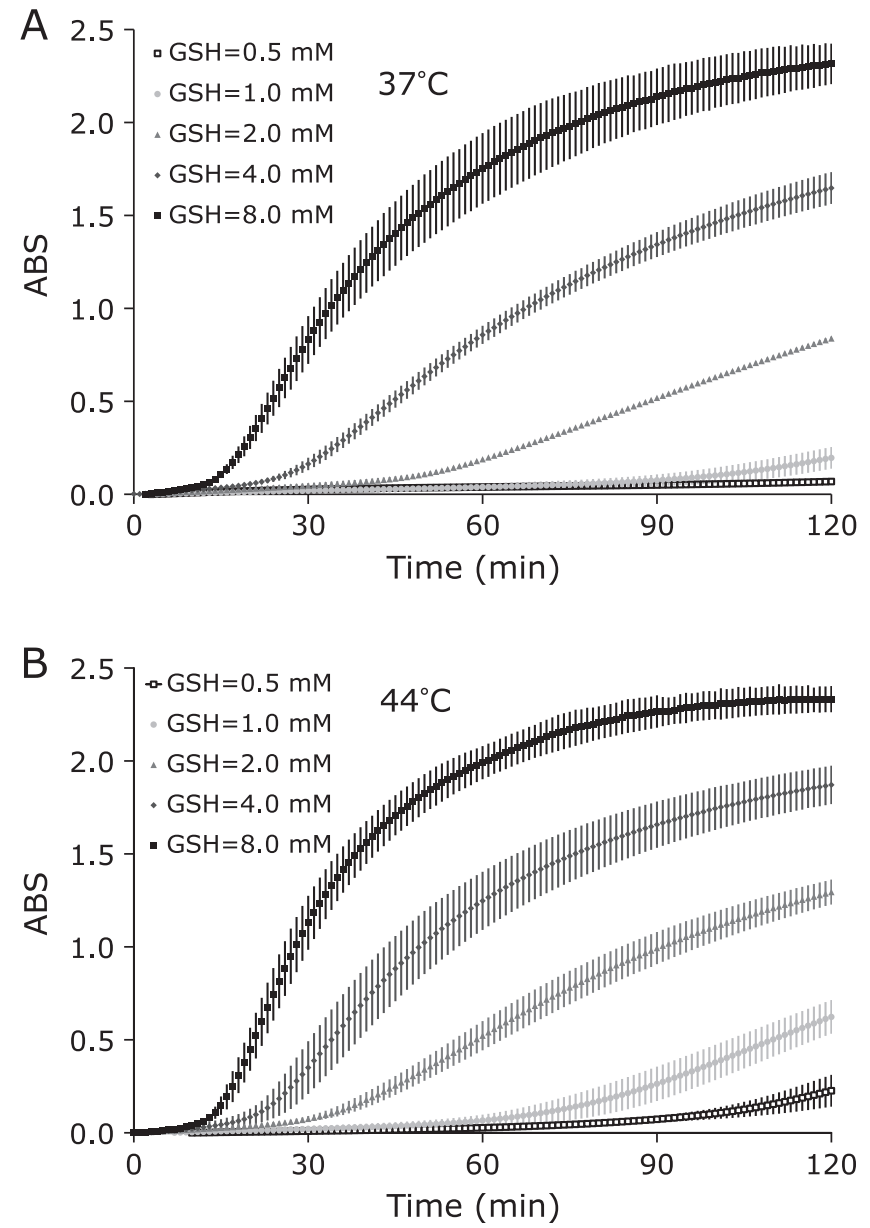

Fig. 5. Effect of GSH concentration on the formation of the blue formazan (reduced NBT). The reaction mixtures containing $1 \mathrm{mM}$ NBT and several different GSH concentrations were incubated at (A) $37^{\circ} \mathrm{C}$ or (B) $44^{\circ} \mathrm{C}$ for $120 \mathrm{~min}$. Values are indicated as averages of triplicated experiments \pm SD. 
generation of $\mathrm{O}_{2}{ }^{\cdot-}$. This result certified that the TEMPOL was working just as a redox detector in the previous paper. ${ }^{(14)}$

No increase of absorbance at $560 \mathrm{~nm}$ was also observed when GSSG was used instead of GSH (Fig. 2B). This result is probably the same as the previous paper, ${ }^{(3)}$ which demonstrated that no TEMPOL reduction was observed when TEMPOL was incubated at $70^{\circ} \mathrm{C}$ with $\mathrm{GSSG}$ instead of $\mathrm{GSH}$, even though the detection method was different to this paper. Oxygen can not extra-oxidize GSSG to make $\mathrm{O}_{2}^{-}$even in a higher temperature. In other words, it can say that GSSG is a stable enough end product of the antioxidative process of GSH. In consequence of stability of the GSSG, the enzymatic system is required to recover GSH from GSSG.

Adding $1.6 \mathrm{U} / \mathrm{ml} \mathrm{SOD}$ or $0.5 \mathrm{~L} / \mathrm{min}_{2}$ gas bubbling could stop the quasi-one-electron-reduction of TEMPOL, i.e., EPR signal decay of TEMPOL, in the previous paper. However, a slight increase of absorbance at $560 \mathrm{~nm}$, reduction of NBT, was still observed in the experiment with $1.6 \mathrm{U} / \mathrm{ml} \mathrm{SOD}$ or $0.5 \mathrm{~L} / \mathrm{min} \mathrm{N}_{2}$ gas bubbling (Fig. $1 \mathrm{C}$ and $2 \mathrm{~B}$ ) in this paper. In the hypoxic condition, GSH could be able to reduce NBT directly rather reduce $\mathrm{O}_{2}$. Since this direct reduction of NBT by GSH in hypoxic condition looks saturated, the reaction is reversible. The direct reduction of NBT by GSH in the hypoxic condition might be not negligibly slow.
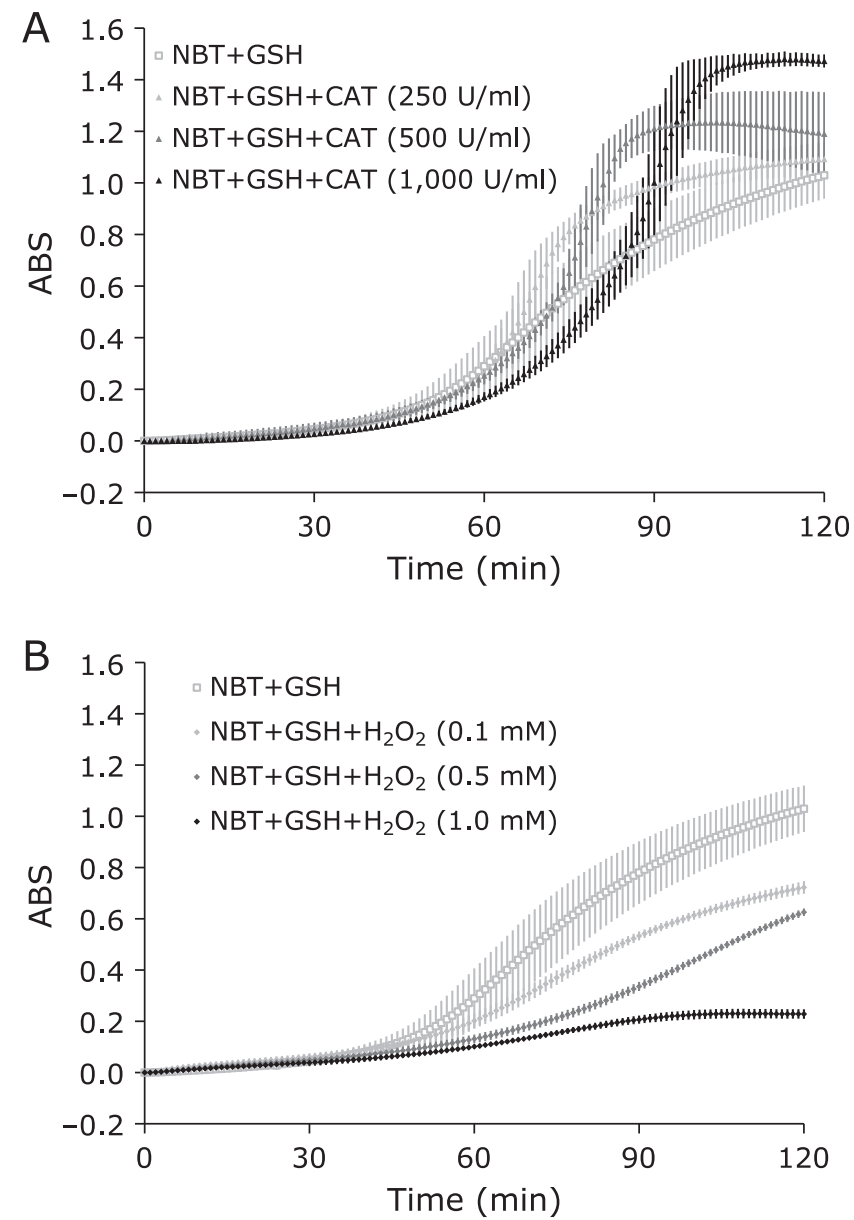

Fig. 6. Effect of catalase and $\mathrm{H}_{2} \mathrm{O}_{2}$ on the formation of the blue formazan (reduced NBT). (A) Effect of catalase. The reaction mixture containing $1.0 \mathrm{mM} \mathrm{NBT}$ and $1.0 \mathrm{mM} \mathrm{GSH}$ was incubated at $44^{\circ} \mathrm{C}$ for 120 min with several concentrations of catalase. (B) Effect of $\mathrm{H}_{2} \mathrm{O}_{2}$. The reaction mixture containing $1.0 \mathrm{mM}$ NBT and $1.0 \mathrm{mM} \mathrm{GSH}$ was incubated at $44^{\circ} \mathrm{C}$ for 120 min with several concentrations of $\mathrm{H}_{2} \mathrm{O}_{2}$. Values are indicated as averages of triplicated experiments \pm SD.
Next, the temperature dependence of the NBT-GSH reaction was tested. The GSH dependent NBT-derived blue formazan generation was exaggerated temperature dependently (Fig. 3). The results of Fig. 2 and 3 suggest that GSH has worked on the temperature dependent generation of $\mathrm{HO}_{2}{ }^{\circ} \mathrm{O}_{2}{ }^{--}$.

When concentration of GSH in the reaction mixture containing $0.1 \mathrm{mM}$ TEMPOL was varied from $0.5-8.0 \mathrm{mM}$, decay of TEMPOL became slower depending on the GSH concentration (Fig. 4A and B). At $37^{\circ} \mathrm{C}$, TEMPOL reduction was almost stopped by $8.0 \mathrm{mM}$ GSH. At $44^{\circ} \mathrm{C}$, the effect of GSH concentration was mild compared to the experiment at $37^{\circ} \mathrm{C}$. The timing of steep decay of TEMPOL reduction was delayed when GSH concentration increased. GSH itself may able to reduce $\mathrm{HO}_{2}{ }^{\cdot}$ directly, in other words the $\mathrm{HO}_{2}{ }^{\circ}$, a relatively strong oxidant, can oxidize GSH as [Eq. 5].

$$
2 \mathrm{GSH}+2 \mathrm{HO}_{2} \cdot \rightarrow \mathrm{GSSG}+2 \mathrm{H}_{2} \mathrm{O}_{2}
$$

In short, $\mathrm{GSH}$ can consume $\mathrm{HO}_{2}{ }^{\circ}$, and suppress the process of one-electron-oxidation of TEMPOL. GSH and TEMPOL competes with each other for $\mathrm{HO}_{2}$.

In the previous paper, ${ }^{(14)}$ the steep decay of TEMPOL following the initial delay time was shift to the right, i.e., delayed, by adding albumin and/or ascorbic acid. Albumin, which can be readily oxidized has been known as an antioxidative biomolecule. Ascorbic acid has been known as relatively strong reductant, which can be easily oxidized in other words. Both molecules, therfore, can be oxidized by $\mathrm{HO}_{2} \cdot$. This can be said that the both molecules can consume $\mathrm{HO}_{2}{ }^{\circ}$. Initial consumption of $\mathrm{HO}_{2}{ }^{\circ}$ can delay the reaction and push the slope to the right.

In an interesting twist, the formation of the blue formazan, i.e., absorbance at $560 \mathrm{~nm}$, increased when the GSH concentration increased in the reaction mixture containing NBT (Fig. 5). The maximum level of blue formazan formation with $8 \mathrm{mM}$ GSH at 120 min incubation was similar level in either $37^{\circ} \mathrm{C}$ or $44^{\circ} \mathrm{C}$ experiment, although the reaction at $44^{\circ} \mathrm{C}$ was slightly faster than that at $37^{\circ} \mathrm{C}$. However, the maximum level of blue formazan

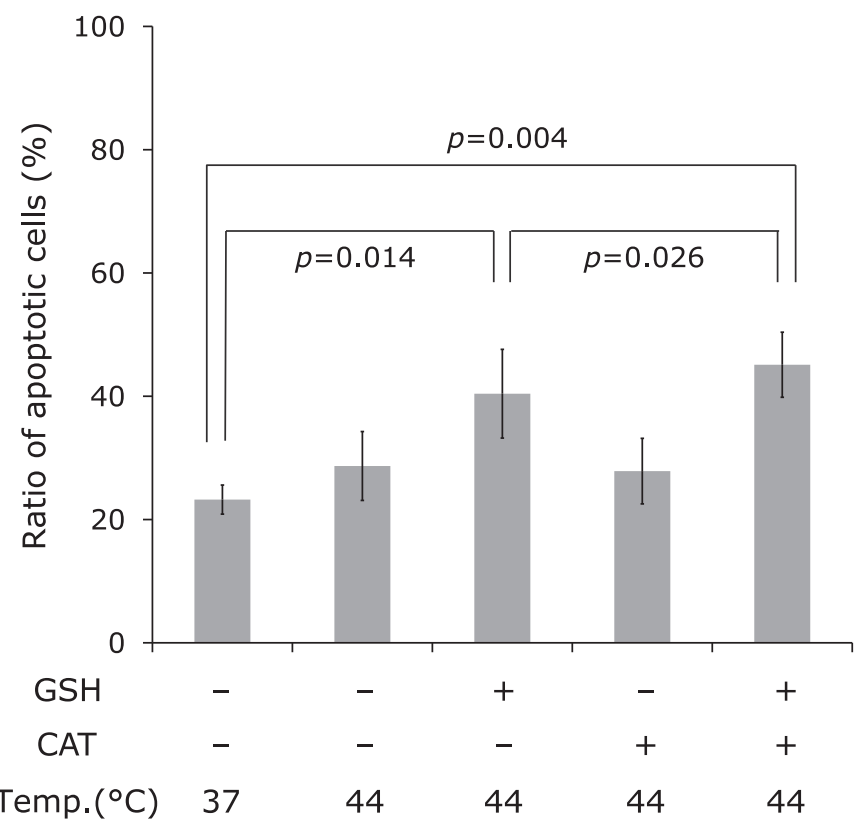

Fig. 7. Effect of coexisting GSH and catalase with a hyperthermic stress task to the mouse thymus cell culture. Mouse thymus cells were incubated with $1 \mathrm{mM} \mathrm{GSH}$ at $44^{\circ} \mathrm{C}$ for $120 \mathrm{~min}$ with or without catalase. Then the cells were washed and again incubated at $37^{\circ} \mathrm{C}$ for an extra $120 \mathrm{~min}$. Values are indicated as averages of triplicated experiments \pm SD. Significance was certified when the calculated $p$ value was less than 0.05 . 
formation with 0.5 or $1.0 \mathrm{mM}$ GSH at $120 \mathrm{~min}$ incubation was around 3 times more at $37^{\circ} \mathrm{C}$ compared to $44^{\circ} \mathrm{C}$ experiment. In addition, the formation of blue formazan with $8 \mathrm{mM}$ GSH was suppressed only around $10 \%$ by adding $3.2 \mathrm{U} / \mathrm{ml}$ SOD in the reaction mixture. This is more like direct reduction of NBT by GSH.

Reaction of NBT and $\mathrm{O}_{2}^{--}$may be sufficiently faster than consumption of $\mathrm{HO}_{2}{ }^{-}$by GSH. NBT can consume $\mathrm{O}_{2}{ }^{-{ }^{-}}$and brake an equivalent balance of the $\mathrm{HO}_{2}{ }^{\circ} / \mathrm{O}_{2}{ }^{--}$population. Therefore, $\mathrm{HO}_{2}{ }^{\circ}$ must be rapidly changed to $\mathrm{O}_{2}{ }^{-}$before being reduced by GSH. The reduction of NBT can be exaggerated by increasing GSH concentration, which can work not only direct reduction of NBT but also work on increasing $\mathrm{O}_{2}{ }^{--}$production.

Additionally to the [Eq. 5], $\mathrm{H}_{2} \mathrm{O}_{2}$ could be yielded by the reaction of a pair of $\mathrm{HO}_{2}{ }^{\circ}$ [Eq. 6], and then the $\mathrm{H}_{2} \mathrm{O}_{2}$ could consume the $\mathrm{O}_{2}{ }^{--}$.

$$
\begin{aligned}
& \mathrm{HO}_{2}{ }^{-}+\mathrm{HO}_{2}{ }^{-} \rightarrow \mathrm{H}_{2} \mathrm{O}_{2}+\mathrm{O}_{2} \\
& \mathrm{H}_{2} \mathrm{O}_{2}+\mathrm{O}_{2}^{\cdot-} \rightarrow \mathrm{OH}^{-}+{ }^{\cdot} \mathrm{OH}+\mathrm{O}_{2}
\end{aligned}
$$

The reaction of [Eq. 7] can make a hydroxyl radical ( $\left.{ }^{\circ} \mathrm{OH}\right)$. This reaction may be harmful due to the high reactivity of the product, i.e., $\mathrm{OH}$, if the reaction occurs in an intracellular space. However, the extracellular generation of ${ }^{\circ} \mathrm{OH}$ may not be lethally important, since ${ }^{\circ} \mathrm{OH}$ could immediately be deleted by extracellular molecules due to its super-high reactivity and could not reach to the intracellular bio-functional molecules. Membrane permeable $\mathrm{HO}_{2}{ }^{\circ}$ and/or $\mathrm{H}_{2} \mathrm{O}_{2}$ can have a chance to give lethal effects on cells.

To confirm the reaction of [Eq. 5, 6, and 7], the effect of CAT and $\mathrm{H}_{2} \mathrm{O}_{2}$ was tested. Addition of CAT to the reaction mixture enhanced the maximum amount of the blue formazan formation dose dependently (Fig. 5A). Conversely, addition of $\mathrm{H}_{2} \mathrm{O}_{2}$ to the reaction mixture suppressed the formation of the blue formazan with dose dependent manner (Fig. 5B). These results suggest that the generation of $\mathrm{H}_{2} \mathrm{O}_{2}$ in the reaction mixture was expected and then the $\mathrm{H}_{2} \mathrm{O}_{2}$ is consuming the $\mathrm{GSH}$-induced $\mathrm{O}_{2}{ }^{--}$. The trigger of the GSH-dependent TEMPOL reduction is one-electron-oxidation of TEMPOL by $\mathrm{HO}_{2}{ }^{\circ}$. Catalase could slightly accelerate GSHdependent TEMPOL reduction but not significantly (data not

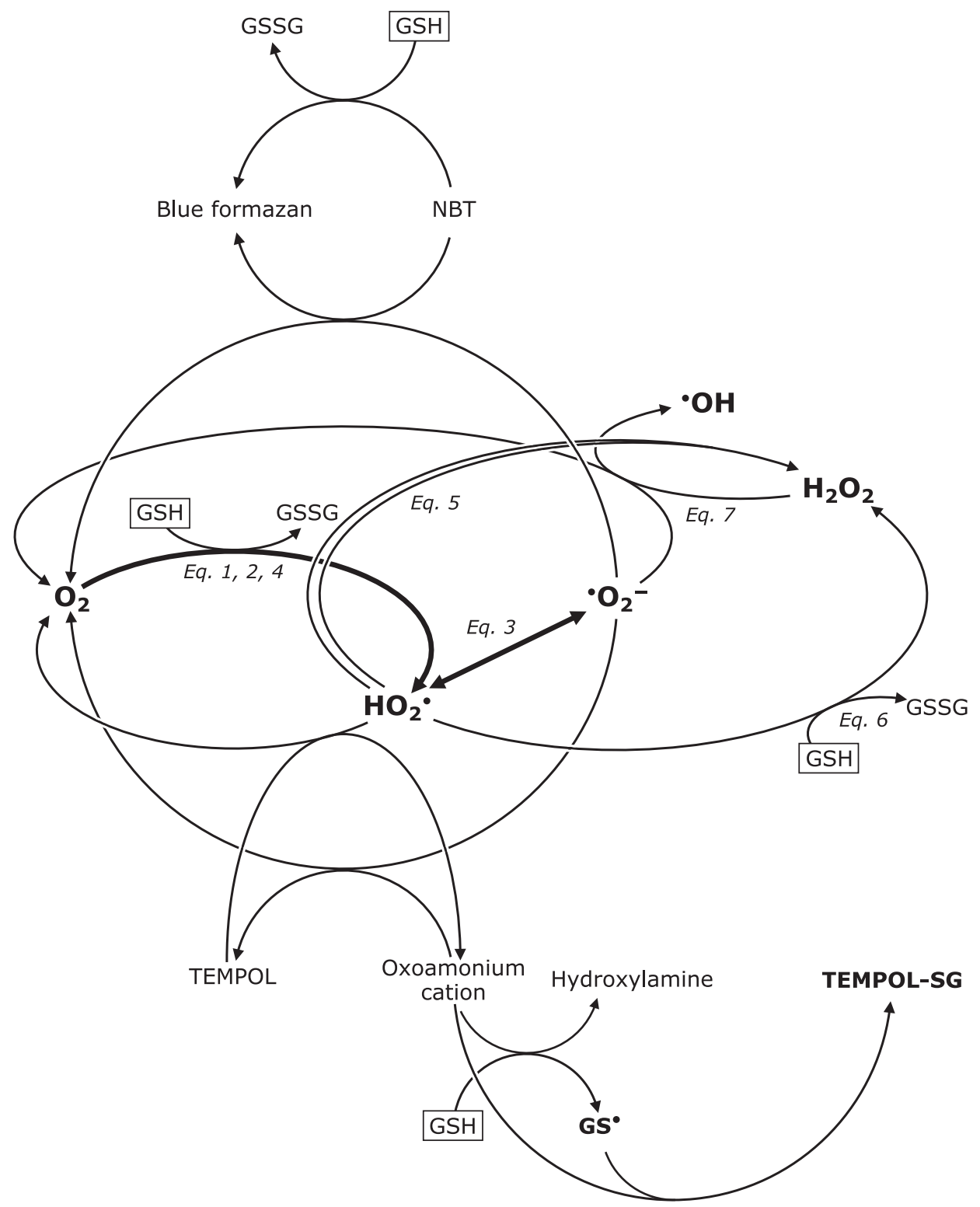

Fig. 8. A schematic drawing of reactions observed in this paper. 
shown), since elimination of $\mathrm{H}_{2} \mathrm{O}_{2}$, which is a consumer of $\mathrm{O}_{2}{ }^{--}$, can move the population of [Eq. 3] left.

Fig. 7 shows the result of the cell survival test using mouse thymus cells. Incubating thymus cells at $44^{\circ} \mathrm{C}$ for $2 \mathrm{~h}$ in PBS could cause apoptosis, i.e., cell size shrank. Incubating thymus cells at $44^{\circ} \mathrm{C}$ for $2 \mathrm{~h}$ in PBS containing $1 \mathrm{mM}$ GSH caused higher apoptosis levels. Incubating thymus cells at $44^{\circ} \mathrm{C}$ for $2 \mathrm{~h}$ in PBS containing $1 \mathrm{mM} \mathrm{GSH}$ and $1,000 \mathrm{U} / \mathrm{ml}$ catalase caused apoptosis more and the percentage of shrunk cells increased.

Fig. 8 shows a schematic drawing of reactions observed in this paper. GSH may reduce $\mathrm{O}_{2}$ to make $\mathrm{HO}_{2}{ }^{\circ}$, which is equilibrated with $\mathrm{O}_{2}{ }^{-}$in an aqueous condition. TEMPOL or NBT was used as a detector of $\mathrm{GSH}$-induced $\mathrm{HO}_{2}{ }^{-}$or $\mathrm{O}_{2}{ }^{--}$generation at hyperthermal temperatures. However, GSH itself can affect the estimation of GSH-induced $\mathrm{HO}_{2}{ }^{\circ}$ or $\mathrm{O}_{2}{ }^{--}$, by reacting with $\mathrm{NBT}$ or $\mathrm{HO}_{2}{ }^{*}$. $\mathrm{HO}_{2}{ }^{\circ}$ can be a source of $\mathrm{H}_{2} \mathrm{O}_{2}$, which can consume $\mathrm{O}_{2}{ }^{--}$. The reactions were actually quite complicated despite the limited number of players; due to the GSH wearing more than one hat. After all, GSH is still a difficult compound which interferes with detecting self-created $\mathrm{HO}_{2}{ }^{\circ} / \mathrm{O}_{2}{ }^{--}$.

$\mathrm{GSH}$ exists in living tissues in $\mathrm{mM}$ level. The in vivo oxygen level can cause GSH-induced TEMPOL reduction, ${ }^{(14)}$ i.e., GSHinduced $\mathrm{HO}_{2}{ }^{-}$or $\mathrm{O}_{2}{ }^{--}$generation, at hyperthermal temperatures. This reaction may be a key for hyperthermia effects. The rapid proceeding of the reaction shown in this in vitro experiment may

\section{References}

1 Gilbert DL, Gerschman R, Ruhm KB, Price WE. The production of hydrogen peroxide by high oxygen pressures. J Gen Physiol 1958; 41: 989-1003.

2 Lehninger AL, Schneider M. Mitochondrial swelling induced by glutathione. J Biophys Biochem Cytol 1959; 5: 109-116.

3 Allen DW, Jandl JH. Oxidative hemolysis and precipitation of hemoglobin. II. Role of thiols in oxidant drug action. J Clin Invest 1961; 40: 454-475.

4 Hoffsten PE, Hunter FE Jr, Gebicki JM, Weinstein J. Formation of "lipid peroxide" under conditions which lead to swelling and lysis of rat liver mitochondria. Biochem Biophys Res Commun 1962; 7: 276-280.

5 Scott AA, Hunter FE Jr. Role of cytochrome C in glutathione induced swelling and lipid peroxidation in liver mitochondria. Biochem Biophys Res Commun 1963; 11: 461-465.

6 Hunter FE Jr, Weinstein J, Scott AA, Schenider AK. The effect of phosphate on glutathione induced lipid peroxidation and swelling in rat liver mitochondria. Biochem Biophys Res Commun 1963; 11: 456-460.

7 Misra HP. Generation of superoxide free radical during the autoxidation of thiols. J Biol Chem 1974; 249: 2151-2155.

8 Brownlee NR, Huttner JJ, Panganamala RV, Cornwell DG. Role of vitamin $\mathrm{E}$ in glutathione-induced oxidant stress: methemoglobin, lipid peroxidation, and hemolysis. J Lipid Res 1977; 18: 635-644.

9 Tien M, Bucher JR, Aust SD. Thiol-dependent lipid peroxidation. Biochem not go in the living cells, since $\mathrm{HO}_{2}{ }^{\circ} \mathrm{O}_{2}{ }^{--}$can not accumulate in living cells. However GSH-induced $\mathrm{HO}_{2}{ }^{\circ} \mathrm{O}_{2}{ }^{--}$may constantly occurred in in vivo situations and it can be accelerated temperature dependently.

The result in this paper suggests that coexisting catalase with $\mathrm{GSH}$ in a reaction mixture could exaggerate $\mathrm{GSH}$-induced $\mathrm{O}_{2}{ }^{-}$ generation at hyperthermal temperatures. Exaggerated extracellular $\mathrm{O}_{2}^{--}$generation could give a harmful effect to living cells.

\section{Conclusion}

Temperature dependent generation of $\mathrm{O}_{2}{ }^{--}$in an aqueous sample containing GSH was again confirmed by the NBT method. GSH may reduce $\mathrm{O}_{2}$ to make $\mathrm{HO}_{2}{ }^{-}$, which is equilibrated with $\mathrm{O}_{2}^{-{ }^{-}}$in an aqueous condition. $\mathrm{H}_{2} \mathrm{O}_{2}$ was also generated simultaneously in this reaction mixture from $\mathrm{HO}_{2}{ }^{-}$, and then $\mathrm{H}_{2} \mathrm{O}_{2}$ consumed $\mathrm{O}_{2}{ }^{--}$. Coexisting catalase in the reaction mixture, as a result, could increase $\mathrm{O}_{2}^{--}$generation. The catalase-exaggerated extracellular $\mathrm{O}_{2}{ }^{--}$generation could give a harmful effect to living cells. This GSH-induced oxidative stress can be a part of mechanisms of hyperthermia therapy.

\section{Conflict of Interest}

No potential conflicts of interest were disclosed.

Biophys Res Commun 1982; 107: 279-285.

10 Paolicchi A, Minotti G, Tonarelli P, et al. Gamma-glutamyl transpeptidasedependent iron reduction and LDL oxidation--a potential mechanism in atherosclerosis. J Investig Med 1999; 47: 151-160.

11 Perego P, Gatti L, Carenini N, Dal Bo L, Zunino F. Apoptosis induced by extracellular glutathione is mediated by $\mathrm{H}_{2} \mathrm{O}_{2}$ production and DNA damage. Int J Cancer 2000; 87: 343-348.

12 Pompella A, Visvikis A, Paolicchi A, De Tata V, Casini AF. The changing faces of glutathione, a cellular protagonist. Biochem Pharmacol 2003; 66: 1499-1503.

13 Matsumoto K, Nyui M, Kamibayashi M, Ozawa T, Nakanishi I, Anzai K. Temperature-dependent free radical reaction in water. $J$ Clin Biochem Nutr 2012; 43: 40-46.

14 Ueno M, Nyui M, Nakanishi I, et al. Scavenging of reactive oxygen species induced by hyperthermia in biological fluid. J Clin Biochem Nutr 2014; 54: 75-80.

15 Sekine-Suzuki E, Nakanishi I, Shimokawa T, Ueno M, Matsumoto K, Murakami T. High-throughput screening of radioprotectors using rat thymocytes. Anal Chem 2013; 85: 7650-7653.

16 Halliwell B, Gutteridge JMC. Free Radicals in Biology and Medicine (5th ed). Oxford: Oxford University Press, 2015; 100. 